\title{
The interjection in old Romanian texts
}

\author{
Margareta Manu Magda* \\ "Iorgu Iordan - Al. Rosetti" Institute of Linguistics, 13 Calea 13 Septembrie, 050711 Bucharest, Romania
}

\section{Article info}

History:

Received June 1, 2017

Accepted July 6, 2017

Published September 30, 2017

Key words:

interjection

diachronic expansion

semantic derivation

old Romanian

modern Romanian

pragmatization

\begin{abstract}
The paper tries to identify the special problems posed by the study of interjection based on the examination of a corpus of texts from the old Romanian (1600-1780), referring to texts from modern Romanian. We have watched how certain interjectional formations have acquired, through diachronic expansion, new grammatical, semantic and pragmatic values.

The structure of the paper is the following: the introduction $(\$ 1)$ summarizes the author's position on the status of the interjection category at a morphosyntactic, semantic and pragmatic level $(\$ 1.1)$ and on the relation between different linguistic structures and their grammaticalization / pragmaticalization process $(\$ 1.2)$. The second section $(\$ 2)$ refers to the specific routes followed by the evolution of the various categories of the analysed interjections, from the old Romanian to the modern Romanian: the presentatives adecă $, i a t a ̆, n i(\$ 2.1)$, the hortatives haide, ni (\$2.2), the addressing particles bre, măi (\$2.3), the connectors with demarcation signal function adevăr, amin (\$2.4). The third section (\$3) has as objective the description of a species of delocutive derivation, illustrated in Romanian by the lexicalized semantic variants of the secondary interjection Doamne!. The study concludes with several final considerations regarding the results of the research $(\$ 4)$.
\end{abstract}

\section{Preliminaries}

1.1. The authors who were recently involved in the study of interjection agree that it has an important function in communication and that its meanings and functions differ from one language to another ${ }^{1}$.

Thus, the Romanian language has an extensive inventory of interjectional formations, recorded and described in works from this domain. For modern Romanian, we have a rich bibliography of the problem ${ }^{2}$. For old Romanian, the description of interjection constructions covers a more limited bibliography ${ }^{3}$.

1.2. In the present study, we will pursue the specific course followed by certain interjections with prototypical values from the old Romanian in their evolution towards modern Romanian. We chose to analyze some of the most representative interjectional formations in the category of presentatives (adec $\breve{a}$, iată, and $n i$ ), of the hortatives (baide and ni), of the addressing particles (bre, măi), of the connectors with demarcation signal functions (adevarr, amin), and of the expressive interjections (the secondary interjection Doamne! 'Lord!'). We will try to present how some of these lexical elements, in conditions of certain contextual morphosyntactic and pragmatic constraints, change their form, meaning and / or function in time (some interjections are grammaticalized / pragmaticalized, consolidating their new status: "grammatical material become more grammatical", Traugott, 1995, p. 15).

\footnotetext{
*Email address: margaretamagda@yahoo.com.

${ }^{1}$ See, in this regard, the "Journal of Pragmatics", vol. 18, iss. 2-3, 1992, dedicated entirely to the study of interjection [online].

${ }^{2}$ For presenting the inventory and typology of interjections from the standard Romanian language, cf. amongst others, GALR, I, Interjecția [The interjection], p. 657-686, and GALR, II, Grupul interjecțional [The interjectional group], p. $119-123$.

${ }^{3}$ Frâncu (2009, p. 151-154; p. 335-336) presents an inventory of the main interjections from the old Romanian language. 
Margareta Manu Magda

1.3. We used, as a theoretical basis, for the linguistic status of interjection, models suggested in the literature of recent years: a) the explanatory (cognitive) model of the process of "subjectification" (see Traugott, 1989 and $1995^{4}$ ) and b) he semantic-pragmatic model specific to the evolution of interjections (see, amongst others, Gonçalves, 2000 and 2002; Hopper \& Traugott, 1993).

1.3.1. Defining aspects of the interjection. The linguistic category of interjection, with its defining traits, exclamative intonation and non-inflection, is a class of heterogeneous words, both grammatically and semantically.

a) From a grammatical point of view, the interjection is a subcategory differentiated by other subcategories $^{5}$ because:

- it is a non-prototypical phrase (an equivalent of the phrase which, like the syntactical fragments of the pro-phrase type, does not present the predicate - subject structure $)^{6}$;

- it is a subcategory whose elements, called by some researchers ${ }^{7}$ linguistic signals, are marks of a non-phrastic act of predication.

b) From the semantic point of view, the interjection is characterized by a vague signification, which allows its use in a large number of contexts that influence its prototypical meaning. These contextual meanings, fixed over time, are conventionalized.

c) From a pragmatic point of view, the category of interjection presents a certain homogeneity considering the performative nature of the definition basis and the ability of the interjection to evolve towards other functional categories. At this level, the interjection interacts with formations such as the exclamation, the vocative, and the imperative, in performing linguistic acts such as warning, injuries, insult, oath or curse, etc.

1.3.2. Premises of semantic derivation. In the theory of grammaticalization, semantic change is expressed through a number of terms such as: bleaching, desemanticization, semantic loss, and weakening; The common denominator of the meaning of these terms is loss. In the typical case of grammaticalization, we are dealing with a redistribution or a sense shift, instead of a loss (Hopper \& Traugott, 1993, p. 84). The "shift" is a gradual process in which forms and constructions, initially expressing primary, concrete, and objective lexical meanings, through repeated use in local syntactic contexts, fulfil more abstract, pragmatic, interpersonal functions based on the speaker's reaction (at Traugott, 1995, p. 32, "subjectification").

\section{Directions of evolution of some interjections from old to modern Romanian}

In the $16^{\text {th }}$ century and in the first half of the $17^{\text {th }}$ century, the inventory of interjection was comprised of numerous inherited or borrowed elements, which disappeared or restrained their use afterwards.

Old Romanian texts highlight a great functional instability of interjective linguistic signals. They present a frequently recognizable evolution in the diachrony (through coexisting forms in synchrony). Due to the semantic equivalence between some interjections and various parts of speech (verbs, pronouns, adjectives, or adverbs), interjections or interjectional groups built around interjection can occupy syntactic positions equivalent to those classes of words $s^{8}$.

\footnotetext{
${ }^{4}$ In Traugott (1995, p. 46), "subjectification" is defined as the development of a grammatical expression in relation to the attitude or belief of the speaker as to what he is saying.

${ }^{5}$ According to authors such as Cuenca (1997), Cuenca \& Hilferty (1999), Gonçalves (2000), etc.

${ }^{6}$ Cf. Gonçalves (2000, p. 4): „tous les équivalents de la phrase qui ne présentent pas de structure sujet-prédicat, comme les fragments syntagmatiques, les pro-phrases, etc. sont donc des phrases non prototypiques. Les interjections constituent alors une sous-catégorie de la catégorie grammaticale de niveau basique fragment."

${ }^{7}$ Cf. Olivier (1985), who classifies linguistic signals in "signaux linguistiques anonymes, formules interpersonnelles stéréotypées et interjections".

8 "Between the class of interjection and the other classes of words there are two-way passages: words belonging to other classes become secondary interjections, totally or partially losing their basic meaning and developing emotional, expressive values, and interjections can be the basis of derivation for verbs and nouns, In general (accidentally, and for adjectives), by suf-
} 


\subsection{The presentatives adică, iată, ni 'that is; here we are'}

The presentative interjection is the main grammatical means of performing the presentation in Romanian? In the $16^{\text {th }}$ century, the prototypical presentative interjections are adecă and iată, competing forms that develop divergently. The former became specialized in time with a prototype trademark value of the reformulation, losing the presentation function; after a while the two senses coexisted at the level of the texts ${ }^{10}$. Regionally, there are also recorded iani, iane, and $n i^{11}$ 'look'. Some of these forms are polysemantic, and can be used to express various ways of presentation. The same brand may correspond to a range of different functions relative to the type of construction or context.

Here are some variants of the quoted presentations, illustrating the glide, and finally the grammatical status change we were talking about.

\subsection{1. $A D I C \breve{A}^{12}$ (with the variants adecă and adăcă), 'here,' 'look' (adverb $\rightarrow$ interjection $\rightarrow$ reformulation connector)}

Having the primary value of an adverb, its interjectional use is particularly frequent in the literary and non-literary texts of the researched age: "adică is in full competition with iată (iacă)" (Frâncu, 2009, p. 151). The following uses have been identified in the texts: presentative sense (presentation of existence and identity) (1); value of reinforcement, initialization of those presented in an administrative act $(2 \mathrm{a}, \mathrm{b})$; quoting meaning (element) (3); explanatory sense (shifting towards the value of the reformulation connector) $(4 a-c)$.

(1) Patriarșii încep cîntare: Adecă, Dumnezeul nostru înălță-se. ( CC $\left.^{2} .1581,194\right)$ 'The patriarchs begin to sing: behold our God rising.'

(2) a. Adecă eu, Marin o(t) Boldești, scris-am acest zapis [a]l meu [...] cum să se știe că am vîndut ocina din Scroviște. (Dî, VII, Zapis de vînzare, Dîmbovița sau Prahova, 1582)

'Behold I, Marin o(t) Boldești, wrote this act of mine [...] so that it is known that I sold the domain from Scroviște.'

b. Adecă eu, Iorga, feciorul buscăi de Bunești, scri<u> eu și mărtu<risesc>. (Dî, CIV, Zapis de cumpărare, Bunești - j. Vaslui, [1595-1597])

'Behold I, Iorga, the son of the beard of Bunești, I write and confess.'

fixing or articulation, the attachment of noun or adjective desinences or of noun determinants (as more frequent procedures)." (Croitor, in GALR, I, p. 677).

'The prototypical presentations, for the class in question, are iată 'here' (iacă, iacătă, ia(n)) și uite (uitați) and their popular variants: ete, iete, iote, oite, uiche, uie, ute, belonging to the category of conative interjections, "which contribute to the acquaintance", by the allocutor, of an "offer" (intent) of the locutor. For an inventory of Romanian presentations, cf. ?, DEX, MDA s.v.

10 "Presentatives are predicates with an NP / DP or a clausal complement, or parenthetical markers. Parenthetical presentatives may be pragmaticalized as focalizers or discourse connectors. In the $16^{\text {th }}$ century (see Manu Magda, 2014), adecă and iată are in competition, since they have very similar functions; adecă is the only presentative marker in $\mathrm{CP}^{1} .1577$ and Ps.1573-8 and it is the most frequent one in PH.1500-10, Св.1559-60, CV.1563-83, while iată is preferred in СТ.1560-1, $\mathrm{CC}^{1} .1567, \mathrm{CC}^{2} .1581$; in PO, the form iaca prevails (Zafiu, 2015a). In the second OR period, adecă (which is less integrated into the syntactic structure from the earliest texts) loses its presentative function (except for some legal formulas) and becomes a prototypical paraphrastic reformulation marker (Zafiu, 2015a; Zamfir, 2015; \$4.8.2). In MR, iată preserves all its functions, while adding new pragmatic values; iaca and iacătă also continue to be presentatives, but they are restricted to the colloquial register" (Zafiu, in SOR, p. 602).

${ }^{11}$ Cf. N. Drăganu, Preface to CTd.1600-40, p. 150: "Hașdeu (Cuv. II, p. 112 and 235) saw in the forms ini and iani the Latin en (cf. Old Gr., Pol. ano, anu, North Serb. ano, Slav. na, Hung. ne, ni, Germ. nu, na, which are all related in phonetics and meaning). Today one can hear $\hat{\imath} n$, ian, or $z a n i$ and $n i$. Ini may correspond to Lat. $e n, n i$ is of Hungarian origin, and $i a n i$ and iane are much more likely to be composed from $i a$ («Wohl nicht Lat. eja, sondern Alb., Bulg. ia», Tiktin-Rum.-Deutsches Wb., p. 746) with Hungarian ni, ne - ia+ni, ia+ne (cf. also Tiktin, ibid., p. 748)”. See also Frâncu (2009, p. 154).

${ }^{12}$,Word of controversial origin (after DA, of unknown origin, after Philippide, Principii de istoria limbii [Principles of Language History], p. 7, from id est quort or ad id quod, the latter etymology also being adopted by Scriban (DLR), after Procopovici, Dacor. X, 79 from adest eccum, after Ciorănescu from Lat. adeque 'alike, the same')” (apud Frâncu, 2009, p. 151). 
Margareta Manu Magda

(3) Că zice svînta scriptură: Blaže (n) mu(ž), adecă „Ferice de bărbatul ce nu mearge spre sfatul necuraților și pre calea păcătoșilor”. (Dî, LIX, Însemnare, Galați, 1570-1571)

'That Holy Scripture says: Blaže(n) mu(ž), that is, happy of the man who does not go on the way of the unclean ones and of the sinners.'

(4) a. Dupăcuvîntulce grăise, că „mainainte”, zice, „de cemăverichema, zic: Adecă, eu”" (cc ${ }^{2} .1581$, 20)

'After the word he had said (that), he said, «when you call me, I say: behold, I.»'

b. Ce adecă, aceastea toate să le părăsim și să meargem după Hristos. $\left(\mathrm{CC}^{2} .1581,75\right)$

'That is, we must all leave them and follow Christ.'

c. Ce se zice limbile, adecă cum ai zice, împreună tot omul ce-i smeri păcatului. ( $\mathrm{CC}^{2} .1581$, 558)

'What do the tongues say, just as you would say, all the men that humiliate them sin.'

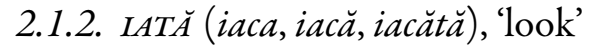

(demonstrative value $\rightarrow$ prezentative interjection $\rightarrow$ argumentative value / connector)

Initially used in a "demonstrative" sense (with the purpose of drawing the attention of the author on the actual and singularizing presence of an object in the reference world by directing it to the later), the interjection iată has entered into Romanian from Bulgarian $(<\text { eto, ete, etc. })^{13}$, most probably via church texts, in Romanian written texts of different kinds, initially following the pattern of use taken from the Slavonic text and subsequently developing other contextual meanings.

Simultaneously with the cult form, the interjection iată has also entered the language by popular (dialectal) means, in variants like ete/iete, etc., in the southern (Oltenian, Wallachian) subdialects, competing with the local form and creating new forms contaminated by the latter $(5 \mathrm{a}, \mathrm{b})$ :

(5) a. Am treierat și cu caii, ete aici chiar aveam aria (TDO, 335)

'I hustled with the horses, look, here I really had the area.'

b. Bre, tataie, iote-așa, iote-așa, și noi avem un berbec! (TDM II, 498)

'Bre, grandfather, look-here, look-here, we also have a ram!'

Traditionally, iată has specialized in making textual (written) presentation ${ }^{14}$. In the analysed texts, it acquires all the fundamental values specific to presentatives: presentative sense per se (presentation of existence and identity) (6a-d); value of intensification of those presented in an administrative act (7); argumentative value (8).

(6) a. Şi iată acestu om al mieu ce am tremes la domniia-voastră, el este frate acelui fecior. (Dî, Scrisoare, Transilvania, 1599-1600)

'And behold, this man of mine whom I sent to your Your Lordship, he is (a) brother (of) that son.'

b. Zise Rabila: „Iaca, aicea Bala, slujnica mea”. (po.1582, cap. 30, 3)

'Rahila said, «Behold, this Bala, my maidservant.»'

c. Iosif, iară, zise: „Iaca, unde sănt”. (PO.1582, cap. 37, 14)

'Joseph also said, «Behold, where I am.»'

\footnotetext{
${ }^{13}$ IATĂ! Interj. 1. Voilà; Voiçi, 2. Voilà que (soudain) [...] From Bulg. Jato, idem (eto, ete, etc. Eto če ... 'here it is'); (DA, s.v.).

${ }^{14}$ Iată 'here' refers to the relative existence of a being that can be approached in a customized manner or not. The strong semantic value we refer to justifies the very frequent use of this presentation in religious texts, where the necessity of confirming with absolute certainty the divine existence and its works is obligatory. Iată gradually expanded its functionality into the literary texts. In colloquial oral communication, this intercession is almost entirely absent. The rhetoric based on the large use of textual presentations in argumentation is sometimes found in current official speeches and, recently, is very productive in spoken media communication. Regarding the behaviour of presentation in modern Romanian, see Manu Magda (2009a).
} 
d. Iaca, domnu-mieu cu aceaea unde eu sănt la el, pre nemică grije nu purtă. (po.1582, cap. 30, 39)

'Behold, my lord, with those with whom I am to him, he does not take care of anything.'

(7) Iată eu egumenul și tot săborul de la mănăstirea de la Muldoviță. (Dî, LXXXII, Scrisoare, Suceava, Mănăstirea Modovița, [30 iunie 1592])

'Behold I, the egumen and all the saber from the monastery of Muldoviță.'

(8) Și neavind cine o lega, iată jiupîneasa Tămășoaie grecoaia să află [de] o deade la meșter de o legă, ca să aibă și ea pomeană. (Dî, LIX, Însemnare, Galaţi, 1570-1571)

'Behold wife Tămăşoaie, the Greek woman, decided to give it to the craftsman to bind it, so that she may also have a charity.'

\subsubsection{Formations in evolution}

Presentative interjections (as well as the injunctive ones - see below) tend to take over the grammatical position of the verb $b^{15}(9,10)$, which is also reinforced by the presence in the context of a complementizer - here, $c \ddot{a}$ 'that' $(9 \mathrm{a}-\mathrm{c}, 10)$.

(9) a. Iaca că am început a grăi cu Domnul (po.1582, 59)

'Behold, I began to speak with the Lord.'

b. Care lucru iată că şi fu (ICP 1700, 88v)

'Which thing, behold that even happened'

c. Ce, cumu-m zise, eu și făcui, și iacătă că văz! (Po.1582, 185)

'What, as he said to me, I even did, and behold that, I see!'

d. Iată-ți muiarea ta (Po.1582, 45)

'Here's your wife.'

e. Iacătă-l undeşade $\left(\mathrm{A} .1620,11^{\mathrm{r}}\right)$

'Here it is where he's sitting.'

(10) Oprită fu bunătatea de prepămînt dentr-acealea zile de ce fusease zis: „Adecă, că se voru lăsa casele voastre pustii". ( $\left.\mathrm{CC}^{2} .1581,211\right)$

'... of what had been said: «That's that your homes will be left deserted.»'

In the $16^{\text {th }}$ century, the two presentations discussed above sometimes coexist in the same context $(11 \mathrm{a}, \mathrm{b})$ (Densusianu, 1961, II, p. 161, apud Zafiu, in SOR, p. 604); "adecă occupies the first place (equivalent to a connector) and iată the second position (acting as a focalizer)" (Zafiu, in soR, p. 604).

a. Demîneața iară, adecă iaca Liia (PO.1582, 98)

'In the morning again, behold (behold) it was Leah.'

b. Adecă, iată, carei se delungă de tine, pier. $\left(\mathrm{CC}^{2} .1581,15\right)$

'Behold (behold), those who depart from you, perish.'

In their evolution towards modern Romanian, the presentatives develop pragmatic values of connectors such as the narrative connector, marking discontinuity or surprise (12a), especially after temporal or conditional constructions (Avram, 1960, p. 47, apud Zafiu, in soR, p. 604), conclusive connector (12b), etc.

(12) a. Ce cugetînd el aceastea, iată îngerul Domnului și să arătă lui. (NT.1648, $3^{\text {v }}$ )

'Thinking of these, behold the angel of the Lord came and showed himself to him in his sleep.'

b. Căzu adecă soțul lui, la picioarele lui (NT.1648, 24 $4^{\mathrm{r}}$ )

'Behold his husband fell down at his feet.'

\footnotetext{
15 “They may have a predicate function, accepting some of the verbs' complements (direct complement, expressed by noun, pronouns, including by clitic, or propositional, possessive dative, supplementary predicative)" (Croitor, in GALR, I, p. 674).
} 


\subsection{Hortative interjections}

Hortative interjections have a more complex diachronic journey than the presentatives, in their evolution from and towards other lexico-grammatical classes.

\subsubsection{BLEM (bleți, blemați), PAS $(\breve{A}), v \breve{A}$}

(verbal forms $\rightarrow$ interjections $\rightarrow$ disappeared in modern Romanian)

In the Early Romanian Age, characterized by the greater rigour of the rhetorical patterns used in the drafting, as well as by the low presence of the orality elements specific to the dialogues, the texts contain interjections, coming from verbal imperative forms with directive meaning, such as blem, bleți, blemați ${ }^{16}$ (13a,b),pas $(\breve{a})^{17}(14 \mathrm{a}-\mathrm{d})$, and $v \breve{a}^{18}(15 \mathrm{a}-\mathrm{e})$, isolated in late Romanian and replaced by other forms, of the interjectional type (the colloquial element of Turkish origin hai(de), and the element of Hungarian origin $n i^{19}$, with the variants iane / iani) (see infra, \$2.3.2).

(13) a. Dzisă: „Blem, frate Ciacal, [...]” (CD.1698, 70)

'He said, «Come on, brother Ciacal.»'

b. Blăm de-m arată. (A.1620,72)

'Come on, show me.'

(14) a. Pasă, pasă, Alexandre, că ție nu e dat să lăcuiești tu cu noi. (A.1620, 32)

'Go, go, Alexandre (voc.M.SG), that it's not your place to live with us together.'

b. Filoane, pasă dară și-i zi să iasă Alexandru. (A.1620, 5)

'Filoane (voc.M.sG), still go and tell him that Alexandru should get out.'

c. Pasă lăuntru la faraon și dzi aceasta lui (po.1582, cap. 8, 1)

'Go in to the Pharaoh and tell him this'

d. Şi pasă înaintea lui pre țărmurile apeei. (Po.1582, cap. 7, 15)

'And (you) go before him on the shores of the water.'

a. Dzise fata lui faraon ei: „Vă!” (po.1582, cap. 2, 8)

'The daughter of Pharaoh said (un)to her: «go away!»'

b. Vă, derept aceaea, și adună într-una bărbații lu Izdrail. (po.1582, cap. 3,16)

'Therefore, go and gather/bring together the men of Israel.'

c. Zise Ietro lui: „Vă cu pace!” (Po.1582, cap. 4, 18)

'Jethro said to him, «Go with peace!»'

d. „Vă înaintea lu Moisi în pustie!” (po.1582, cap. 4, 27)

'«Go in front of Moses in the wilderness!»'

e. Vă la faraon, măne demăneață. (Po.1582, cap. 7, 15)

'Go to the Pharaoh tomorrow morning.'

\subsubsection{NI, LANE (iani)}

2.2.2.1. The interjection $n i$ with a hortative meaning, after an imperative or conjunctive (16a-e), identified both in the Northern and Southern texts of the $16^{\text {th }}$ century, restricts its usage to the north, being attested today with presentative value, and only in regional dialects $(17,18)$.

\footnotetext{
${ }^{16}$ Cf. DEX-online, s.v. BLEM (BL $\left.\breve{A M}\right)$ - (obsolete) "This archaism in Maramureș is heard less often and only in a few villages” (T,iplea, 1906, p. 432). - Lat. ambulo, ambulare ('to walk') > imbla(re) 'walk' > umbla 'to walk'. Besides words formed in Romanian with the prefix în- (îm-), used with and without prefix: bătrîni / îmbătrîni, tineri / întineri, sănătoși / insănătoși, bucur / imbucura etc., here, too, has been used the form without $\hat{\imath} m-$, considering it to be a prefix and not an inherited word (Felecan, 1994, p. 38).

${ }^{17} \mathrm{Cf}$. DEX-online, s.v. $P \breve{A S} \bar{A}^{2}, 3^{\text {rd }}$ pers. pásă.

${ }^{18}$ Cf. DEX-online, s.v. $V \breve{A}$ (Lat. vade).

${ }^{19}$ Cf. DEX-online, s.v. $N I$ interj.
} 


\section{Old Romanian}

(16) a. Ni, să dzidim o cetate și turnul cui vărvul să agiungă la ceriu. (Po.1582, cap. 11,4)

'Let's build a fortress and its tower and peak shall reach the sky.'

b. Ni, săpogorîm gios și să turburăm limba lor. (po.1582, cap. 11,7)

'Let's descend and influence their language.'

c. Derept aceasta, ni, să dăm vin a bea tatălui nostru. (Po.1582, cap. 19, 32)

'As a consequence, let's give wine for our father to drink.'

d. Zise Laban: „Ni, batăr, aşa să fie cum dzici”. (po.1582, cap. 30, 34)

'Laban said, «Come on, be it as you say.»'

e. Ni, deaca amu ai vrut să te duci [...], derept-ce ai furat domnedzeii miei? (po.1582, cap. 31, 30)

'Look, if you wanted to go now and you lamented so loud at your Lord's house, why did you steal my gods?'

\section{Dialectal Romanian}

$N i$ (< Hung. nez) is today a presentative interjection with limited regional circulation (Central and North-Western Transylvania). Having in general the meaning of uite 'look', it primarily functions as an intensifier, alone or in combination with other markers of the same category (17a,b). Most commonly, this presentative is associated with ostensive deictics (demonstrative pronouns, adjectives and adverbs, personal pronouns of the $3^{\text {rd }}$ person, as well as definite articles), manifesting various stages of stereotyping $(18 \mathrm{a}-\mathrm{c})^{20}$.

a. „nii!" zîce „, se lup mare iesă colo pe dos” // „undi-i?” // (TDN, 41)

'«Look,» he says, «what a great wolf is going out down there» // «where is it?»'

b. d-apăi uite ni! / primăvara / adică iarna no / le grijîm acasă // (TDN, 85)

'then look / in spring / namely in winter no / we take care of them at home //'

a. ciobanu care-i rîndu să dușe cu oile / iestălalt stă... de la stîna / pe rînd așa ni // (TDN, 223) 'the shepherd to whom the turn comes goes with the sheep / the other stays ... from the sheepfold / in turn look so //'

b. avea cuptoriu / din casă / și un ciubăr aşa ni / une merea [...] băga lemnile aşa ni // înc-amu am de-alea ni // (TDN, 224)

'he had the oven / from the house / and a little buck like that [...] he puts the wood look so // I still have look, some of these //'

2.2.2.2. Regionally, iane, iani 'behold' are also recorded(19). Frâncu (2009, p. 154) notes that just like ni, iane (iani) < ia + ne "after 1600, gradually restricts its use to some Nordic texts: iane (Cv.1563-83, 20v/12; $\left.\mathrm{CC}^{2} .1581,315,364,407\right)$, iani (?, XII, 100 $/ 11$, XIV, 113 ${ }^{\mathrm{r}} / 5,8$; СTd.1600-40, 102 $\left.{ }^{\mathrm{r}} / 2,16,110^{\mathrm{v}} / 1\right)$ ”.

(19) Iane a-mu trupe (cтd.1600-40, 110 $)$

'Here is my body'

\subsection{3. $\operatorname{HAI}(D E)^{21}$}

(hortative interjection with multiple contextual uses $\rightarrow$ imperative value $\rightarrow$ connector)

In the late Romanian period, at the same time as the appearance of oral, colloquial elements in the analysed texts, there are registered the hortative interjections of Turkish origin hai(di/de) (with wide circulation in

\footnotetext{
${ }^{20}$ For this topic, see Manu Magda (2009b).

${ }^{21}$ See, for example, TDRG, s.v.: "türk. hayde, $-d i$, $-d a$; in allen Nachbar- u. Balkansprachen.
} 
Margareta Manu Magda

the Balkans) ${ }^{22}$, which extend over time (in the spoken language and less in written literary Romanian, with the exception of press style), imposing themselves in modern colloquial Romanian, sliding to the verb status (it presents a beginning of a desinence paradigm, like that of the interjections poftim, uite) ${ }^{23}$.

By its own nature ${ }^{24}$, it was characterized as the typical interjection of Romanian interaction ${ }^{25}$. This allocutive form is specialized for communication in dialogue structures that necessarily presuppose the presence (either real or imaginary) of an addressee. For this reason, the interjection in question penetrates later in the written version of Romanian, especially in the texts of the fictional style, where it takes the place of the imperatives blem, pas $(\breve{a}), i a(n i)$, preserving the value of the imperatives it often accompanies (20a) and tending to replace it $(20 b-d)$ (by joining the vocative $-(20 c, d)^{26}$.

\section{Old Romanian}

(20) a. Una dintre dînsele zise cître cealaltă: - Hai să ne coborîm aici. (CPR, 207)

'One of them said to the other: «Let's get down here.»'

b. Au dzis copilului: „Hai ghidi cahpol!” (NL 1750-66, 222)

'They said to the child, «Come on, [cahpol] that you are!»'

c. Hai mare prislestiață ce ești. (CD.1698, 160)

'Come on, great [prislestiață] that you are.'

d. Haide, prietine, vino să-ți arăt cîte feluri de bucate facem astăzi (CPR, 235)

'Come on, my friend, come here to show you how many dishes we make today'

\section{MODERn Romanian}

Although it belongs, by definition, to a class of inflexible words, the interjection hai(de), with imperative value, presents, in modern Romanian, a beginning of inflection (having forms with the verbal desinence of the $2^{\text {nd }}$ person singular, $-t ̦ i$ : haideți (21a) or the verbal desinence of the $1^{\text {st }}$ person plural, $-m$ : haidem $(21 b-d)$; the latter has a narrower sphere of use - "popular and obsolete").

a. A: Haideți să-ncercăm. (IVRLA, 193)

'A: (you) Let's try.'

b. - Aimée, știi ce? Haidem la Constanța!

- Haidem! rosti ea spontan...

- Atunci haidem în vagonul-restaurant pentru refacere.

- Haidem, Aimée, e timpul să mergem.

(M. Drumeș, Invitație la vals, apud Pană Dindelegan (2009), p. 533-536)

'- Aimée, you know what? (we) Let's go to Constanța!

- (we) Let's go! spontaneously she said...

- Then (we) let's go to the restaurant-car for refreshing.

- (we) Let's go! Aimée, it's time to go.'

c. S,i-i șopti: - Haidem la Sala Catalană.

(M. Eliade, Maitreyi şi alte proze, apud Pană Dindelegan (2009), p. 533-536)

'And he whispered, «Come on to the Catalan Hall.»'

\footnotetext{
${ }^{22}$ These are considered (see Frâncu, 2009, p. 335) innovations of the pre-Phanariot and Phanariot era (1640-1680).

${ }^{23}$ To describe the status of these interjections in modern Romanian see, among others, Manu Magda (2009a).

${ }^{24}$ Closely related to the imperative, hortative interjections have some common features with vocative and imperative: they can appear isolated in the phrase, they speak with a special intonation and serve to address us; that is why these interjections can accompany a vocation or imperative. (GALR, I, p. 667).

${ }^{25}$ The wording belongs to Rodica Zafiu (2005).

${ }^{26}$ Contextually, the interjection hai (de) interjection can be associated or (more and more commonly) assimilated: with an imperative (or a performative expression), or with the hortative conjunctive. In the initial use, the term hai (de) was associated with the imperative of verbs of movement ("Come, come! Let's go!"). In this configuration, hai (de) exhibits the combinatorial availability of the substituted verb. See, in this regard, DEX-online, s.v. Hai.
} 
d. Vă rog și vă implor să haidem insuportabili stînd și înțelepți...

Haidem să fim rude, i-am spus...

Haidem să ne mișcăm, îmbrățişarea vieții mele.

(N. Stănescu, Epica Magna, apud Pană Dindelegan (2009), p. 533-536)

'Please, and I beg you to come out unbearable, standing and wise ...

(we) Let's be relatives, - I told her ...

Let's move, (you) embrace of my life.'

In certain contexts, hai(de) joins the elements of the language that are meant to refer to the components of the communicative act, operating as a discursive marker. In monologues, the interjection hai (de) has the character of a discursive connector (in clustered formulæ), marking various argumentative roles (directing the decoding of the intentions an utterance was formulated with $)^{27}$.

\subsection{Addressing interjections ${ }^{28}$}

\subsubsection{BRE, $M \breve{A I}$}

(interjection with "popular" connotation $\rightarrow$ interjection with "familiar" connotation $\rightarrow$ vocative value)

\section{LATE OLD ROMANIAN}

Addressing and phatic interjections are absent from old texts. They appear sporadically in the first fictional texts of the late $19^{\text {th }}$ and $20^{\text {th }}$ century ${ }^{29}$ literature to dominate all the modern Romanian contexts, where they sometimes tend to take over the grammatical behaviour of the vocative (often preceding one noun in vocative, which they form an intonational unit with, or take its place $)^{30}$.
a. Bre, hei, om necunoscătoriu... (CD.1698, 125)
'Bre, hey, ignorant man!'
b. Ce ți-i voia, măi? (NL 1750-66, 21)
'What do you want, măi?'

2.3.2. BRE, $M \breve{A I}, M \breve{A}, F \breve{A}, M \breve{A R E} E^{31}$ (the last term gone out of use)

\section{$19^{\text {TH }}$ CENTURY ROMANIAN}

The most frequent addressing interjections in the $19^{\text {th }}$ century ${ }^{32}$ are: bre, măi, mă, fă, măre:
a. Nu vă temeți, măre, lăsați”” (N. Filimon)
'«Do not be afraid, măre, leave it alone (you.PL).»'
b. „Fa, fa Ioană” (V. Alecsandri)
'«Fa, fa, Ioană (VOC.F.SG) »'
c. „Of! mări frate” (V. Alecsandri)
'«Oh! mări, brother»

\footnotetext{
${ }^{27}$ See GALR, II, Conectori frastici şi transfrastici [Phrastic and transphrastic connectors], \$3.2, and Manu Magda (2009a, p. 482-483).

28 "Interjections by which the recipient is called are called addressing or appellative. There is some sort of structuring in them, by specializing some interjections for recipients with the trait [+ Human]: hei, măa, măi, fa/fă, alo, băa băi, bre, pst... In many situations, the addressing interjections accompany nouns in the vocative case, thus strengthening their addressing value. Of the interjections with recipients [+ Human], only $f a / f a ̈$ is specialized for female recipients, as a result of its origin from the noun fată 'girl'” (Croitor, in GALR, I, p. 667).

${ }^{29}$ See, for this subject, Chivu et al. (2015).

${ }^{30}$ See Manu Magda, in GALR, II, p. 893-895.

${ }^{31}$ MẮRE interj. 1) (used to express wonder, perplexity, curiosity). 2) (also used as an addressing term) Măi. [Var. mări] / cf. Alb. more, Modern Gr. moré (NODEX, 2002, s.v.).

${ }^{32}$ Apud Croitor, in Chivu et al. (2015, p. 276-281).
} 


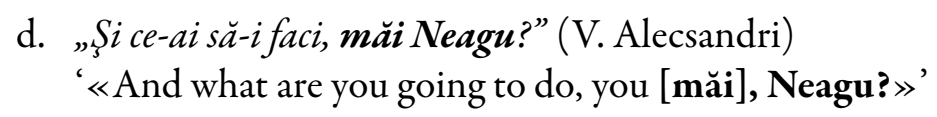

\section{MODERn ROMANIAN}

In using these terms of interpellation that express the call to contact the speakers and stimulate the commencement of communication ( $h e i, e i, e, m a \ddot{a} i, m \breve{a}, b \breve{a} i, b \breve{a}, b r e, f a, f a a, f a \ddot{i}, t u)^{33}$ structural and functional changes occur in time. The terms in question are mainly used in non-standard (regional, popular) registers. The exceptions are mă!, măi!, present even in the familiar communication of some categories of educated speakers (for example in the spoken media). In this respect, there is a tendency to weaken the intensity of use of the politeness formulæ and to reinforce the value of the interjectional calls mă, bă, băi, bre, $t u$.

(24) a. Măi Mărine, te mai pui cioban la vară? Mă pui, bă nea Ioane. (TDo, 997)

'Măi Mărine (voc.M.SG), you're still hiring as a shepherd this summer? I hire myself, bă Uncle Ioan(e) (voc.M.sG)'

b. Mă, nu știu dacăți-e de folos ce ți-am spus eu. (IVLRA: 42)

'Mă, I do not know if it's useful for you what I told you.'

c. - Vrei să mă conduci acuma pă mine pă la spate... Băi, dumneata vrei să-ți spui ceva? (?, 2004).

'You want to drive me to my back... Băi, do you want me to tell you something?'

- Caragiale avea o vorbă: „Ce să caute neamțtu' in Bulgaria?” "Ce caută, bă, românu' in Irak, băi?!”, Ce cauți, bă, la noi, bă? Cin'te-a trimis?” (?, 2003).

'- Caragiale had a saying: «What is the German looking for in Bulgaria?» «What is the Romanian, bă, looking for in Iraq, băi?!» «What are you looking for, bă, at us, bă? Who sent you?»’

d. A: Măi! Eu spun o chestie foarte serioasă! Dă bine, mă!

B: Stați, bă!... (?, 2003).

'A: Măi! I am telling you a very serious thing! It looks good, mă!

B: Let me tell you (DAT.PL), bă! ...'

\subsection{Interjections with transphrastic connector value}

\subsubsection{ADEV̆̈R (AT) (Lat. ad + de + verum) $)^{34}$ and $\operatorname{AMIN}^{35}$ (Slav. aminŭ $<$ Gr. amin, Hebr. amen)}

Interjections can have different communication values (noted above) or can function as pragmatic connectors. With this last function, some are specialized in certain contexts: amin, bogdaproste, aleluia, and osana belong to the ritualized religious language. Others are used, for example, as demarcation signals in administrative texts (letters, official documents, laws) that require concise, unambiguous expression. In essence, these signals highlight the instructions contained in the text to which they are attached. (See the case of the archaic, isolated, clustered interjections ${ }^{36}$ adevăr $(25 a-c)$ and amin $(26 a-c)$. The former is out of use, the latter is used today only in the church language.)

\section{Documents}

\footnotetext{
${ }^{33}$ Cf. Manu Magda, in GALR, II, p. 893-895.

${ }^{34}$ See DEX-online, s.v. adevărát ${ }^{2},-\breve{a}$.

${ }^{35}$ There are a series of (actual) interjections borrowed from other languages. Some loans were made in the old language (aleluia 'hallelujah', amin 'amen', osana 'hosanna' from Slavic, bogdaproste 'thank you, God bless you' from Bulgarian, bre from Turkish, haide from Turkish, Bulgarian and Modern Greek, etc.), others in modern and contemporary times (Croitor, in GALR, 2008, I, \$5.1). In DEX-online, s.v. AMÍN interj. 1) (it is used as a concluding formula in religious texts, prayers, etc.) True; so be it. 2) fam. It's over!; Farewell! / < Slav. aminu, source: ? (2002).

36 "The tendency of natural languages is to cloud the procedural sense of success and to form collocations of quasi-stable originally free expressions” (Ștefănescu, 2007, p. 215).
} 
(25) a. Adevăr, făcut-am tocmeală, ce Domneata ai trimes credincios<ul> măriii tale de credință [...] (Dî, XXXI, Scrisoare, Transilvania,1600)

'Indeed, I've made a deal, by which you have sent the man of faith of your greatness with this commandment and promise of your kingdom'

b. Şi să fut Dumiile-voastre sănătos, adevăr. (Dî, XCVII, Scrisoare, Suceava, [1593-1597])

'And your lordship be healthy, indeed.'

c. Păntru aceaea dăm știre domiitale și să te veselești de la Dumnedzău, adevăru. (Dî, CX, Scrisoare, Suceava, [1600])

'That's why we let you know and [we wish you] to be glad from God, indeed.'

(26) a. Dumnezeu pre mijloc de noi. Amin. (Dî, XVI, Zapis de vînzare, J. Prahova, 1597-1600)

'God among us. Amen.'

b. De-această vă dămu în știre și Dumnezeu să vă ție sănătoși și întru pace bună, amin. (Dî,, XVIII, Tîrgoviște, [1599])

'That's why we let you know and God keep you healthy and in good peace, amen.'

c. Dumnezeu lungească zilele domitale, amin. (Dî,, XCIII, Scrisoare, [1593])

'May God extend the days of your lordship, amen.'

\section{Old RELigious literature}

(27) a. ... şi acmu și purure și în veci adevăru. $\left(?, 69^{\mathrm{r}}\right)$

'... and now and forever and forever the truth'

b. Așteptămu scularé morților. di vecie vecului. adevăru. (?, 121 ${ }^{\mathrm{v}}$ )

'We are waiting for the resurrection of the dead. forever. the truth.'

c. Că aceasta amu, adevăr, bună iaste și cu folos și spăsenie. ( $\left.\mathrm{CC}^{2} .1581,25\right)$

'Like now this is, indeed, good and useful and penitence.'

(28) a. iarî direpții | intru părîțiia ceriului. $\mid \operatorname{amin}\left(?, 106^{\mathrm{v}}\right)$

'and the righteous / in the kingdom of heaven. / amen'

b. Că a lui e slava și ținearea, intru nesfirșiţii veacii veacilor, amin. $\left(\mathrm{CC}^{2} .1581,107\right)$

'That's his glory and the keeping, in the end of the ages of the ages, amen.'

\section{Emotional interjections: the case of the secondary interjection Doamne!}

\subsection{Secondary interjections}

Linguistics habitually distinguishes between primary interjections, which always have interjectional use, and secondary interjections ${ }^{37}$, which have interjectional use by virtue of their significance (Ameka, 1992, p. 105).

All secondary interjections fall into the subclass of intrinsic interjections and have an emotive communicative function. They generally come from nouns ${ }^{38}$ and, to a lesser extent, from verbs, adverbs, pronouns, and nominal phrases. The sub-class of secondary interjections also includes prepositional groups and petrified sentences.

\footnotetext{
37 "Secondary or improper interjections are created on the field of the Romanian language from other parts of the speech or from different phrases or sentences which, after frequent use and accentuation of affective value, have acquired the status of interjections. When used with interjectional value, these words or groups of words totally or partially lose their own lexical meaning, acquiring additional affective nuances and changing their grammatical behavior, being morphologically invariant and syntactically independent." (see Croitor, in GALR, I, Interjecția [Interjection], \$5.1).

${ }^{38}$ The nouns that can become secondary interjections are grouped into several semantic classes: kinship names (mamă 'mother', măiculiță 'mummy', tată 'father', frate 'brother', soră 'sister'), nouns from the religious sphere (Dumnezeu 'God', Domn 'Lord', drac 'devil', naiba 'heck', păcat 'sin'), frequently used terms of address (domn 'gentleman', nene 'mister'), seldom proper nouns” (Croitor, în GALR, I, Interjecția [Interjection], \$5.1.1).
} 


\subsection{Premises of semantic derivation}

3.2.1. Below, we will briefly illustrate the behaviour of the prototypical secondary interjection Doamne! ( Dumnezeule!) 'Lord! ( God!)' in the consulted old Romanian texts, compared to the one in modern Romanian texts ${ }^{39}$.

Doamne! ( Dumnezeule!) belongs to the class of interjection formulæ that include, at a synchronic level, several stages of a derivative chronology. We will briefly outline the stages of the delocutionary derivation of the term, starting from the use of the nominal form of the appellative in a prayer situation (considered as the implicit discursive situational context), to its interjectional, stereotyped one. This situation is created by a speaker who sets up an act of implicit language (with double meaning_ "begging" and "praise" - at the same time) appropriate to the situation, together with an addressee, through and for the dialogue, an implicit speech act. Delocutive derivation, from the nominal to the interjectional form of the term, is based just on this double meaning of contextually implicit act of language.

3.2.2. The basic form for the semantic derivation of the word, in the process of sliding to the secondary interjection value, is the nominal, allocutive one, with the function of an appeal formula addressed to divinity, during the prayer. $\operatorname{Domn}(<\operatorname{DOMM}(\breve{\mathrm{I}})$ NUS, nominative) is used, with this function, especially with vocative desinence, Doamne (< DŎMĬNE): - as a term of addressing the divinity $(29 \mathrm{a}-\mathrm{d})$; - as a generic term of addressing the "master, prince" $(30 \mathrm{a}-\mathrm{b})$; - as a generic common term of polite addressing to a male, domnule 'sir” (articulated vocative) / plural domnilor (30c).

a. Doamne, spăseaște-ne! $\left(\mathrm{CC}^{2} .1581,109\right)$

'Lord, deliver us!'

b. Milosîrd ești tu, Doamne! ( $\left.\mathrm{Cc}^{2} .1581,65 / 67\right)$

'Lord, you are merciful!'

c. Domnul den ceriu, iartă-ne noi. (CLRV.1559, 66)

'Our Lord in Heaven, forgive us.'

d. Dumnezeu, cu urechile noastre auzim. (CLRV.1570, 96)

'God, we listen with our ears.'

(30) a. Doamne impărate (FD.1592-604, 168) 'Lord emperor'

b. Zise: "Rogu-te, Doamne, <s>ă am aflat mila înaintea ochilor tăi, nu încungiura sluga ta" (Po.1582, cap. 18, 3)

'He said, «Please, Lord, if I have found mercy before your eyes, do not enclose your servant $\gg ’$

c. Domnilor și boierilor (CLM.1700-50, 293) 'Lords and boyars'

\subsection{Stages of derivation}

In what follows, we will consider, in agreement with Olivier (2000, p. 161f.), that the interjective formations, identified in various contexts, represent lexicalized realizations / achievements from the diachronic point of view of a semantic continuum ${ }^{40}$. This continuum contains several stages:

3.3.1. The basic stage (primitive situation) of the derivative process contains the formula Doamne!, with a nominal function, as a support for all other stages. The expressive potential of the formula (31) derives

\footnotetext{
${ }^{39}$ In this regard, see our work, Manu Magda (2017).

${ }^{40} \mathrm{See}$, in this sense, Olivier (2000): “...nous ferons l'hypothèse d'un continuum sémantique reliant ces différents emplois. Selon nous, on ne peut conclure à une véritable polysémie : chaque emploi porte la trace des types d'emplois qui le précèdent dans l'ordre dérivationnel... chaque emploi porte la trace des types d'emplois qui le précèdent dans l'ordre dérivationnel. La classe des formules interjectives laisse voir dans un même état de langue plusieurs étapes d'une chronologie dérivationnelle” (p. 161).
} 
from the fact that the meaning of the term benefits from the persistence, in the speaker's memory, of the prototypical content of prayer implicit in the appeal formula.

(31) Aceasta grăiia, că de acmu zis ifu „Doamne, spăseaște-ne!” ( cC $\left.^{2} .1581,109\right)$

'This was what he said, «Lord, deliver us!»'

3.3.2. The first interjectional stage of expression is characterized by a weakening of the prototypical situation "prayer" (through the ambiguity of the author's identity), and the exclusive preservation of the "exceptional situation" value from its semantic sphere.

Old Romanian

Old Romanian texts mark this stage by using (and improving the process in the late phase of the studied period) conventional rhetorical techniques (among which the exclamation has a privileged role, see 33ac). In the conversational triangle speaker - addressee - witness, the speaker (through discursive elements) organizes and directs the discussion, ensures a favourable atmosphere for communication, prefiguring a dialogue with a potential receptor $(32 \mathrm{a}-\mathrm{d})$, which has an active role in the creation of meanings. "Due to the addressed speech, the recipient ceases to be an abstract, virtual entity, becoming an integral part of a dialogue construct, in which to him is assigned the role of a confidant, but also a co-participant in the formation of the text" (Cvasnîi Cătănescu, 2006, p. 75).

(32) a. Ceși David amu răpștind arătă-se: „Pînă cîndpăcătoșii, Doamne, pînă cînd păcătoşii laudă$s e$ ?" $\left(\mathrm{CC}^{2} .1581,2\right)$

'What David also now shows up is saying: «Until when the sinners, Lord, until when the sinners will they boast?»'

b. Şidzise Avraam: // „Doamne Domnezeu, den cevoiu cunoaştecă voibirui acesta?” (po.1582, cap. 15,8$)$

'And Abraham said: // «Lord, God, how will I know that I will overcome it?»'

c. Că pre adevărat, Doamne, au călcat împărații Asiriei limbile și păgînii. (?, 71)

'That indeed, Lord, Assyria's kings have transgressed the languages and the heathen, and put their gods into the fire.'

d. "Ce este omul, Doamne, de-ai făcutpentru el atîta mărire?” (?, 294)

'«What is the man, Lord, that you have made for him such greatness?»'

(33) a. Doamne, Domnul nostru, cît iaste de minunat numele tău [...]! (?, 29)

'Lord, our Lord, how wonderful your name is, the whole earth is full of it!'

b. O, cît sîntu de infricoşate lucrurile tale, Doamne! (?, 63)

'Oh, how terrible your things are, Lord!'

c. O, Doamne, impăratul mieu, atîta dragoste și pateme ai pus pentru noi. (?, 160)

'Oh, God, my emperor, so much love and passion you gave us.'

Although we did not identify the final interjectional stage in the old texts, we attested to the chroniclers two examples marking the very advanced phase of pragmatization, present today in spoken Romanian:

(34) Intr-una de dzile, cu meșterșug i-au împărțit, pre unii la o samă de agii curții sale, la ospățu, văz doamne, pre alții la alți agi și la masa sa... (CLM.1700-50, 227 $7^{\mathrm{r}}$, zac 19)

'One day, by hand, they divided them, some of them at the agas of his courthouse, at the feast, you see, Lord, the others at other agas and keeping some of them at his table.'

(35) Scris-au veziriul cu scîrbă la pașa de Tighine, dzicînd că beiul de Moldova este un ghiaur și știe toate ce să facu la Moscu și la Ieși, de le scrie tot adevărat la Poartă „iar tu ești, vedzi doamne, busurman și nu știi nemic!” (NL 1750-66, 196)

'The vizier wrote in disgust, to the pasha of Tighine, saying that Moldova's bey was a ghiaur and knew everything that was done in Moscu and in Ieși, so that he wrote all true to the Gate «and you are, you see, Lord, bursuman and you know nothing!»' 
3.3.3. In the final interjectional stage, all derived uses of the term Doamne! preserve, from the primitive situation, the emotion characteristic of exclamation and interjective gesture. In this last stage of the delocutive derivation, the term in question achieves an advanced level of pragmatization, acquiring the prototypical function of intensification. Communication loses its primitive sacred substrate and goes into a profane communication. Interjectional Doamne! approaches the value of the accompanying $A b$ ! and $O b$ ! interjections, which mark the high degree of emotivity, but starting from a different primitive situation - that of the cry $(\text { see } 36 a, b)^{41}$.

\section{MODERn Romanian}

In modern Romanian, "Doamne!" has acquired interjectional value because of its special affective content, uttering the name of the supreme divinity. Doamne! loses the role of addressing or calling, as in the situations when used in its own sense, being used in expressing an emotional reaction of interjectional value.

As a secondary interjection, Doamne! performs syntactically (unstructured) independent utterances, prefacing or completing other statements that complement them affectively. The difference from the substantive variant is reflected by intonation ${ }^{42}$.

a. Oh, Doamne, nu poți să-ți imaginezi! O să las o parte din mine, aici, în capitală! (online) 'Oh, God, you can not imagine! I'll leave a part of myself here in the metropolis.'

b. Și vine chelnerița, vede în ziar poza din tinerețe a actorului și zice, topită de emoție: „Vai, Doamne, cît era de frumos!" (online)

'And the waitress comes in, she sees the actor's younger picture and says, melted by emotion: «Oh, my God, how handsome was he!»’

Prototypically, these statements are associated with exclamative syntax ${ }^{43}$. Generated by the formation in question, nominal exclamations usually accompany exclamation constructs ( $w h$-type) ${ }^{44}$ containing syntactic patterns characterized by the presence of exclamatory grading and intensification elements of the adjective or adverb ${ }^{45}$. These statements include, in the first positions of the syntagmatic sequences through which they are made, exclamative elements such as:

- the pronoun (adjective) ce 'what' (37a), sometimes followed by the adverb mai 'more' (37b), the preposition de 'of' $(37 \mathrm{c})$, or by both;

a. Doamne, ce a apărut în Scornicești! E o statuie tare ciudată. (online)

'God, what appeared in Scornicești! It's a weird statue.'

b. Doamne, ce mai viață! (online)

'God, what a life!'

c. Doamne, ce de bani! 400.000.000 de euro „mișcă” finala Champions ... (online)

'God, how much money! 400,000 Euro "moves" the Champions League final...'

- the pronominal adjective cit 'how much' (alone or followed by the preposition de 'of'):

(38) Doamne, cît de mult o iubește! (online)

'God, how much he loves her!'

\footnotetext{
41 “Si l'on arrive au même type d'effet avec $M D$, unité obtenue par dérivation à partir d'une expression à contenu descriptif, qu'avec un cri parlé, c'est bien que la situation primitive de $M D$ se prête à une telle évolution, même si celle-ci n'a rien d'automatique" (Olivier, 2000, p. 172).

42 "The character of the exclamative utterances of interjections is generally marked in the suprasegmental plane" (GALR, II, p. 969).

${ }^{43}$ Cf., in this regard, Vișan (2002, p. 415-424).

${ }^{44}$ Cf. Vișan (2002, p. 416). The author distinguishes between exclamations, statements with a certain expressive illocutionary force, and exclamative constructions, sentences being defined as such according to their semantic-syntactic traits.

${ }^{45}$ See GALR, I, Interjecția, \$4.1. and II, Enunțul, \$4.2.
} 
- unde 'where', cum 'how', unde nu (accompanied, in some constructions, by the adverb mai 'more', placed away from the conjunction):

(39) Doamne, cum a putut să iasă Miron Cozma din casă! (online)

'Lord, how could Miron Cozma come out of the house!'

The intensifying function of the interjection (focus, gradation, modulation) has two components (an explicit and an implicit one):

- the direct address, made by appealing to the Doamne! 'Lord!' (the name of the supreme divinity) contained in the nominal exclamation;

- the involvement of a witness of the highest prestige in the appreciation contained in the exclamational construct that follows the nominal exclamation, and the implication of a linguistic presentation act (uite 'look!').

The communicative functions of the term are an expression of the degree of the speaker's engagement in the communicative act expressed through the exclamation construct, which usually precedes it.

\section{Final considerations}

In the previous pages, we have signaled some aspects of the semantic variability diachronically developed by some of the most significant interjections of Romanian language.

The present paper highlights the fact that certain texts from the $16^{\text {th }}$ century have a large number of forms by which the semantic-pragmatic category of the presentation is realised. These forms are adapted to the specific legal and administrative type of communication they practice. Presentative interjections specific to the written language ( $\operatorname{dec} \breve{a}$, iată) are also identified in the religious literature.

Hortative and addressing interjections, specific to the spoken language, have a lower communicative weight in the old Romanian. They are found in the written language of the pre-Phanariot and Phanariot era.

In the analysed texts, we have recorded forms that have changed their functional status (semantic and grammatical), evolving in several directions:

- from the class of the verb to the class of the interjection or vice versa (presentatives, hortatives);

- from the class of interjection to the name class (conatives);

- from various other morphological classes to the class of interjection (secondary interjections).

By repeated use, with certain values, in identical contexts, some formations tend to undergo pragmati ation, becoming communicative marks.

The investigated formations ensure the functional continuity, keeping in the modern Romanian some of the values already recorded in the old language (registered in dictionaries and identified in texts belonging to the pre-modern period), to which new ones have been added. Thus, we have recorded in modern Romanian the following ${ }^{46}$ :

- the textual presentative interjection iată penetrates the "semi-formal" oral communication, taking over the attributions of the presentative uite (as a mark of perceptive knowledge);

- the colloquial uite, non-existent in early Romanian, in informal and semiformal contexts, accumulates several values - manifesting different degrees of movement to another function than the prototypical one (contributing to the structuring of the discourse, marking the beginning of a dialogue replica or a citation / enumeration sequence, or highlighting some argumentative roles);

- hortative interjections today occupy an important place among the elements that have the function of verbal mobilization and demobilization: hai (de) is the prototypical interjection of linguistic action.

\footnotetext{
${ }^{46}$ For this subject, cf., amongst others, our work, Manu Magda (2009a).
} 
Linguistic formations, such as the analysed secondary interjection Doamne! belong to the category of pragmatized speeches, being especially frequent in the use of the present-day Romanian. They act as communicative markers (intensifying, focusing, grading) in ever-wider contexts of use ${ }^{47}$.

\section{Bibliography}

\section{A. Corpus}

A.1620 = Alexandria, în Zgraon, Fl. (ed.), Cele mai vechi cărți populare în literatura română, vol. 11, Fundația Națională pentru Știință și Artă, București, 2006.

CC $^{2} .1581$ = Coresi, Cartea cu învățătură, ed. S. Pușcariu \& Al. Procopovici, Atelierele Grafice Socec, București, 1914.

CD.1698 = Dimitrie Cantemir, Divanul, în Opere complete, I, Divanul, ed. V. Cândea, București, Editura Academiei, 1974, p. $103-405$.

CLM.1700-50 = Miron Costin, Letopisețul Țărîi Moldovei. Opere, ed. P.P. Panaitescu, Editura de Stat pentru Literatură și Artă, București, 1958.

CLRV = Mareș, Al. (coord.) (2016). Crestomația limbii române vechi, vol. I (1521-1639), Editura Academiei Române, București.

CPR $=$ Cărți Populare Românești, Editura Litera Internațional, București - Chișinău, [f.a.]

CTd.1600-40 = Codicele Todorescu, în Drăganu, N. (ed.), Două manuscripte vechi. Codicele Todorescu şi Codicele Marțian, p. 191-229.

Cs.1609-18 = Codex Sturdzanus, ed. Gh. Chivu, Editura Academiei Române, București, 1993.

Cv.1563-83 = Codicele Voronețean, ed. M. Costinescu, Editura Academiei Române, București, 1981.

Dî = Chivu, Gh., Georgescu, M., Ioniță, M., Mareș, Al. \& Roman-Moraru, Al. (eds) (1979). Documente și însemnări românești din secolul al XVI-lea, Editura Academiei, București.

FD.1592-604 = Floarea darurilor, în Roman Moraru, Al. (ed.) (1996). Cele mai vechi cărți populare în literatura română, 1 , Editura Minerva, București, p. 119-182.

ICP 1700 = Ioan Cantacuzino, Patru apologii pentru religia creştină şi Patru orații, traduse în limba română la mijlocul secolului al XVII-lea de Nicolae Spătarul (Milescu), ed. E. Dima, Editura Universității „Alexandru Ioan Cuza”, Iași, 2010, p. 3-127.

IVRLA = Ionescu-Ruxăndoiu, L. (coord.) (2002). Interacțiunea verbală în limba română actuală. Corpus (selectiv). Schiță de tipologie, Editura Universității din Bucureşti, Bucureşti.

NL 1750-66 = Ion Neculce, Letopisețul, în Ion Neculce, Letopisețul Țării Moldovei și O samă de cuvinte, ed. I. Iordan, Editura de Stat pentru Literatură și Artă, București, ed. a II-a, 1959.

NT.1648 = Simion Ștefan (ed.), Noul Testament (Bălgrad/Alba Iulia), Editura Reîntregirea, Alba Iulia, 1998.

Po.1582 = Palia de la Orăştie, ed. V. Pamfil, Editura Academiei, București, 1968.

TDM II = Texte dialectale, Muntenia. II, publicate sub redacția lui B. Cazacu, de P. Lăzărescu, M. Marin, B. Marinescu, V. Neagoe, R. Pană şi M. Vulpe, Bucureşti, 1975.

TDN = Texte dialectale şi glosar, Bistrița-Năsăud, publicate de M. Marin și M. Tiugan, Consiliul Culturii şi Educației Socialiste, Bucureşti, 1987.

TDO = Texte dialectale, Oltenia, publicate sub redacția lui B. Cazacu, de C. Cohuț, G. Ghiculete, M. Mărdărescu, V. Şuteu şi M. Vulpe, Editura Academiei, Bucureşti, 1967.

\section{B. References}

Ameka, F. (1992). Interjections: The universal yet neglected part of speech, in “Journal of Pragmatics”, vol. 18, nr. 2-3, p. 101-118, Crossref.

Avram, M. (1997). Gramatica pentru toți, Editura Humanitas, București, p. 291-295.

Chivu et al. (eds) (2015). Studii de istorie a limbii române: Morfosintaxa limbii literare în secolele al XIX-lea şi al XX-lea, Editura Academiei Române, București.

Cuenca, M.J. (1997). Defining the indefinable? Interjections (abstract), Fifth International Cognitive Linguistics Conference, Vrij Universiteit, Amsterdam, 14-19 iul.

Cuenca, M.J. \& Hilferty, J. (1999). Introducción a la linguistica cognitiva, Editorial Ariel, Barcelona.

Cvasnîi Cătănescu, M. (2006). Retorică publicistică. De la paratext la text, Editura Universității din București, București.

DA = Academia Română, Dicționarul limbii române, serie veche (literele A-B, C, F-I, D-De, J, L-Lojniță), coordonator Sextil Pușcariu, Socec \& comp. și C. Sfetea, București, 1913-1949.

Felecan, N. (1994). Elemente arhaice latine în graiurile din nordul țării, in "Buletinul științific, seria A, Filologia”, vol. IX, p. 3743.

Frâncu, C. (2009). Gramatica limbii române vechi (1521-1780), Casa Editorială Demiurg, Iași.

\footnotetext{
${ }^{47}$ Similar structures are exhibited by secondary interjections such as “Mamă!” 'mother!' (see Manu Magda, 2009c.
} 
GALR = Guțu Romalo, V. (coord.) (2008). Gramatica limbii romane. I. Cuvântul. II. Enunțul, tiraj nou, revizuit, București, Editura Academiei Române.

GBLR = Pană Dindelegan, G. (coord.) (2010). Gramatica de bază a limbii romane, Editura Univers Enciclopedic, București.

Gonçalves, M. (2000). Sur le statut linguistique de l'interjection, in “Actas del VIII congreso de Lingüística General”, Universidad Autónoma de Madrid, p. 14, [online].

Gonçalves, Miguel (2002). A Interjeição em Português. Contributo para uma Abordagem em Semântica Discursiva, FCT/FCG, Lisboa.

Hopper, P.J. \& Traugott, E. C. (1993). Grammaticalization, ed. I-a, Cambridge University Press, Cambridge (ed. a II-a: 2003).

Manu Magda, M. (2008). Limba română vorbită, in GALR, II, p. 869-904.

Manu Magda, M. (2009a). Indici de alocutivitate în limba română actuală (clasa alocutivelor interjecționale), in Pană Dindelegan, 2009, p. 459-491.

Manu Magda, M. (2009b). Prezentativele în textele dialectale românești, in "Lucrările celui de-al XIII-lea Simpozion Internațional de Dialectologie”, vol. I, Bala Mare, 19-21 sept. 2009, Editura Mega, Cluj-Napoca, p. 189-205.

Manu Magda, M. (2009c). Un alocutiv pragmatizat în limba română, în „Limba română”, vol. LVIII, nr. 2, p. $230-237$.

Manu Magda, M. (2014). Vorbirea directă în texte românești din secolul al XVI-lea, în Zafiu, R. et al. (eds), Limba română: diacronie și sincronie în studiul limbii române, I, Editura Universității din București, București, p. 287-296.

Manu Magda, M. (2017). Gramaticășipragmatică. Un studiu de caz: interjecția Doamne! în limba română, în Dragomirescu, A. et al. (eds), Sintaxa ca mod de a fi. Omagiu doamnei profesoare Gabriela Pană Dindelegan, la aniversare, Editura Universității din București, București, p. 265-276.

Olivier, C. (1985). L'art et la manière : comment dans les stratégies discursives, în „Langages”, vol. 20, nr. 80, déc. 1985, p. 71-98, Crossref.

Olivier, C. (2000). L囚interjection mon Dieu : variabilité sémantique et situations de discours, în „Cahiers de praxématique”, nr. 34, p. 161-189, [online].

Pană Dindelegan, G. (ed.) (2009). Dinamica limbii române actuale, Editura Academiei Române, București.

SOR = Pană Dindelegan, G. (ed.) (2016). The Syntax of Old Romanian, Oxford University Press, Oxford; Anexe online.

Ștefănescu, A. (2007). Conectori pragmatici, Editura Universității din București, București.

TDRG = Tiktin, H. (2004). Rumänisch-Deutsches Wörterbuch, Harrassowitz Verlag, Wiesbaden.

Traugott, E. C. (1989). On the rise of epistemic meanings in English: An example of subjectification in semantic change, in "Language", vol. 65, nr. 1, p. 31-55, Crossref.

Traugott, E. C. (1995). Subjectification and Grammaticalization, în Stein, D. \& Wright, S. (eds), Subjectivity and Subjectivization in Language, p. 31-54, Cambridge University Press, Cambridge.

Vișan, Ruxandra (2002). Observații asupra sintaxei exclamativelor cu ce, ce de, cît și cum în română, in Pană Dindelegan, G. (coord.), Perspective actuale în studiul limbii române: actele colocviului Catedrei de Limba Română, 22-23 noiembrie 2001, Editura Universității din București, București, p. 415-425.

Zafiu, R. (2005). Conjunctiile adversative din limba româna: tipologie si niveluri de incidență, in Pană Dindelegan, G. (coord.), Tradiție și inovație în studiul limbii române, Editura Universității din București, București, p. 239-252. 